University of Nebraska - Lincoln DigitalCommons@University of Nebraska - Lincoln

Library Philosophy and Practice (e-journal)

Libraries at University of Nebraska-Lincoln

3-29-2019

Library Facilities, Sources and Services in the Medical and allied Colleges in Goa State: A Study

Dr. Jayaprakash G. Hugar

Dnyanprassarak Mandal's College and Research Centre, Assagao, Mapusa, Goa, dmclibrarian@rediffmail.com

B. U. Kannappanavar

sahyadri Arts Collge Shimoga Karnataka, India

Follow this and additional works at: https://digitalcommons.unl.edu/libphilprac

Hugar, Dr. Jayaprakash G. and Kannappanavar, B. U., "Library Facilities, Sources and Services in the Medical and allied Colleges in Goa State: A Study" (2019). Library Philosophy and Practice (e-journal). 2310.

https://digitalcommons.unl.edu/libphilprac/2310 


\title{
Library Facilities, Sources and Services in the Medical and allied Colleges in Goa State: A Study
}

\section{Dr. Jayaprakash G Hugar*\& \\ Dr. B. U. Kannappanavar**}

\begin{abstract}
:
Purpose: The purpose of this paper is to determine the true complexion of the present status of the libraries, existing facilities, resources and electronic services available in the government medical, dental, nursing, pharmacy colleges and private nursing, pharmacy, homeopathic and ayurveda medical colleges in the state of Goa.

Methodology: Survey method adopted for the present study. A well-structured questionnaire was designed keeping the objectives in mind and distributed to the respective college librarians and collected the required primary data. Collected data were analyzed using statistical tools with the help of SPSS software.

Findings: It is clear from the study that, $87.5 \%$ college libraries under the study are having less than 5 library staff. $12.5 \%$ college library (i.e. GMC) is having 16 to 20 library staff respectively. The study reveals that, five colleges out of eight colleges under the study are having full time librarians. $12.5 \%$ librarians belonged to less than 30 years, $37.5 \%$ librarians belonged to 31 to 35 years age group and $25 \%$ librarians each is aged between 45 to 50 and more than 50 years age group respectively. The majority of the librarians have experience between 16 to 30 years of experience. All the colleges under the study are not having scientific and technical reports, electronic databases, standards, patents and audio visual collection in their college libraries.
\end{abstract}

Keywords: Library Resources, Services, Internet, Library use, collection of the library.

\section{Corresponding Author:}

* Dr. Jayaprakash G Hugar, Librarian, Dnyanprassarak Mandal's College and Research Centre, Assagao, Bardez, Goa - 403 507. Email: dmclibrarian@rediffmail.com, ORCID No. http://orcid.org/0000-0001-8307-5582.

**Dr. B.U. Kannappanavar, Sahayadri College, Shimoga, Karnataka, email: kannappanavar@gmail.com

\section{Introduction:}


Libraries are considered to be the heart of an education institute. They primarily exist to provide information to the learners. Due to rapid advancement in Information Communication Technology and the free availability of information on the internet, the traditional libraries face a keen competition from hybrid/electronic libraries. Now, a day's users try to get information through internet as it is very easy to search and get information, instead of spending hours together in the library looking for information in the books, journals and others. Currently, libraries are gradually being transformed into knowledge resource centers. They areno longer limited to collection of books and periodicals. Users now require access tonumerous kinds of materials and expertise. The modern library acts as a networking "hub" that collects, manages and disseminatesinformation and knowledge beyond just providing access to a collection of books and otherpublications.

\section{The State of Goa}

Goa enjoys a place of pride in the country as one of the most literate states of India. It has registered an impressive progress in field of education. The State has achieved literacy rate of $87 \%$ with $90 \%$ of male and $84 \%$ of females being literate.

\section{Medical Education in Goa}

The establishment of Medical Education is another landmark in the history of education in Goa. The Portuguese made efforts to initiate medical education in those remote times and overcome the innumerable difficulties which they had to face before they could finally succeed is indeed a remarkable chapter in Portuguese Colonial History.

Medical Education in Goa started in the early $18^{\text {th }}$ century in the Royal Hospital of the old city of Goa. The first historical document, in which the need of medical education in Goa is stressed, is a report of the year 1687 by the Councillor of the State. Cristovao de Sousa Coutinho, who, whilst expressing his views on the proposed transfer of the capital city from Goa to Mormugao, suggested the advisability of starting the teaching of medicine in Goa, in order to create in the territory a permanent nucleus of medical assistance. He said "the natives were very intelligent and would learn it very easily". The suggestion of the Councillor was accepted by the 
Governor Dom Rodrigo da Costa, who sent a proposal to the King of Portugal to send to Goa two or three good physicians, not only to practice but also to teach medicine to native students. It seems that the things did not change until the turn of the century and it was only on $2^{\text {nd }}$ December 1702 that Dr. CiprianoValladares was appointed to teach medicine in the Royal Hospital of Goa. This is therefore, the historical date on which medical education was started in Goa, and Dr. Valladares was the pioneer of medical education. Dr. Valladares was followed by Dr. Rosa Pinto, Dr. Jose da Silva Azavedo, and others successively, and the course continued more or less regularly till 1785. After Dr. Bernardes, no doctor trained in Portugal was available for some time and Goa was without a doctor trained in Portugal for many years, so the teaching of medicine suffered.

The teaching which was interrupted between 1770 and 1785, was reinitiated by Dr. Fagundes, pioneer of teaching of surgery in Goa is improved the medical education. Dr. Barroso da Silva worked in Goa for nearly 35 years and did outstanding professional work, saving many lives and preparing a good number of surgeons.

The first regular medical course in Goa was established in 1801 in the Royal and Military Hospital by Dr. Miranda e Almeida who was a demonstrator and relieving lecturer at the University of Coimbra and was appointed as chief physician of Goa, by the Central Government, on a request made by the Governor VeigaCabrl. By this time, the medical services in the Royal and Military Hospital at Goa were reorganized and the teaching of medicine and surgery was better coordinated under a common direction.

Due to sudden transfer of the Director of Medical Education to Lisbon from 1822 to 1842 medical education had an irregular life and suffered many interruptions. In 1871 the Director, Dr. Fonseca Torrie planned a new reform increasing the number of staff-members to seven professors, three demonstrators, and one relieving professor. He also envisaged the creation of a nursing course. However, this project was never approved.

A new attempt to remodel the course was made in 1888. A committee was appointed to work out a project and the task was performed by Dr. Costa Alvares. In place of the existing 
school, a school of naval and colonial medicine was proposed by the Committee. Besides the traditional course of Medicine and Pharmacy, there was also to be a nursing course. The medical course was to comprise 21 subjects and its duration would be of six years. The Pharmacy course would be of three years duration and would comprise of six subjects. The nursing course was to be of two years. The staff was to be of 10 professors and four relieving professors. The four relieving professors and four out of ten other professors were to be selected from among the degree holders of Goa or Bombay.

This is the history of medical education in the Portuguese possessions of India from its origin to the fall of constitutional monarchy. The Medical School from its foundation in 1842 to 1910 had produced 444 doctors and 135 pharmacists. It is surprising that there were only two Hindus among all these physicians and pharmacists produced up to 1910.

In 1902 there was a move in the Portuguese Parliament which threatened the very existence of the school. It was Dr. Miguel de Mombarda, an eminent professor of the Medical School of Lisbon who then defended it vigorously in the Portuguese Press. He put forth his arguments in a convincing manner and showed why the school should not be closed; but instead developed, so that it might ultimately prove to be a good nucleus of scientific work, and bring both benefit and glory to the Portuguese people. And the school survived. (Pandya, 1982)

\subsection{Pharmacy Education in Goa}

Pharmacy profession in Goa is the oldest in the Indian subcontinent. The first ever Pharmacy course was introduced along with the medical course in 1842 at the old Portuguese school known as "Escola Medica de Goa and later named as "Escola Medica Cirurgica de Goa". The Pharmacists (Farmaceuticos) and Doctors (Medico Cirurgiao) were educated and trained in the same medical school and they had almost the same status in the Goan Society.

The only available source of information is an undocumented article by Cordeiro,

wherein it was stated that 'with the doctors coming from Portugal, there was always a pharmacist. In the year 1846 a Medical School was opened and in the same school there was a School of Pharmacy also (Varadan, 1954-1955). 
Presently, we have one government sponsored and another one self-financing pharmacy college imparting diploma, bachelor and master degree courses in pharmacy subject.

\subsection{Nursing Education in Goa}

Nursing education was started in Goa by the Portuguese during the $15^{\text {th }}$ Century, the first of its kind in Asia. Besides the traditional course of Medicine and Pharmacy, there was also to be a two years nursing course. After liberation of Goa in 1961, the old nursing education courses were gradually phased out and in their place the Government of India started new nursing courses according to the Indian Nursing Council Regulations. The Auxiliary Nurse Midwifery Course was started in September 1964 and the General Nursing Midwifery Course was started in September 1965 with technical assistance from WHO and other help from UNICEF. The Post Basic B.Sc. Nursing course was conducted from 1993-2006. In August 2005 the B.Sc. Nursing Course (Basic) was started. (Institute of Nursing Education, 2010 - 2011)

At present three nursing colleges are providing nursing education in Goa. All the colleges are having diploma and bachelor's degree courses in nursing, affiliated to Goa University and recognised by Maharashtra Nursing Council and Indian Nursing Council. (Directorate of Technical Education, 2011)

\section{Objective of the Study}

The main objective of the study is to know the true complexion of the present status of the libraries, existing facilities, resources and electronic services available in the Government and Private Medical and allied College Libraries in Goa. To study the existing library conditions (library facility, library personnel, library resources and services). And to make suggestions for a modern user oriented library services.

\section{Scope and Limitation of the Study}

Scope of this study was limited to the full time and Part-time teachers and students of professional colleges that tooeach four (medical, dental, nursing and pharmacy) colleges in the government and private sector. The study has been limited to the eight medicine and allied colleges affiliated to Goa University only. 


\section{Methodology}

Survey method was adopted; structured questionnaires are distributed to all thecollege librarians followed by interviews to get full information about the functioning of their college libraries.

\section{Results and Discussions}

Table 8.1

Year of Establishment of colleges and their Libraries

\begin{tabular}{|l|c|c|c|c|c|c|}
\hline \multirow{2}{*}{ Name of the Institutions } & \multicolumn{6}{c|}{ Year of Establishment } \\
\cline { 2 - 7 } & $\mathbf{1 9 6 3}$ & $\mathbf{1 9 8 0}$ & $\mathbf{1 9 9 3}$ & $\mathbf{1 9 9 8}$ & $\mathbf{2 0 0 5}$ & $\mathbf{2 0 0 7}$ \\
\hline Goa Dental College & - & $\begin{array}{c}1 \\
(12.5)\end{array}$ & - & - & - & - \\
\hline Goa Medical College & $\begin{array}{c}1 \\
(12.5)\end{array}$ & - & - & - & - & - \\
\hline Goa College of Pharmacy & $\begin{array}{c}1 \\
(12.5)\end{array}$ & - & - & - & - & - \\
\hline $\begin{array}{l}\text { B.S.P's GomantakAyurvedic } \\
\text { College }\end{array}$ & - & - & $\begin{array}{c}1 \\
(12.5)\end{array}$ & - & - & - \\
\hline K Homeopathic College & - & - & - & 1 & - & - \\
\hline PESC Pharmacy & - & - & - & - & - & 1 \\
\hline Inst. Nrsg. Edu. & - & - & 1 & - & - & - \\
\hline VMRF College of Nrsg. & - & - & - & - & 1 & - \\
\hline \multicolumn{1}{|c|}{ Total } & $\begin{array}{c}2 \\
(25.0)\end{array}$ & $\begin{array}{c}1 \\
(12.5)\end{array}$ & $\begin{array}{c}2 \\
(25.0)\end{array}$ & $\begin{array}{c}1 \\
(12.5)\end{array}$ & $\begin{array}{c}1 \\
(12.5)\end{array}$ & $\begin{array}{c}1 \\
(12.5)\end{array}$ \\
\hline
\end{tabular}

Table-1 indicates establishment year of college and their libraries. First Medical college i.e.:- Goa Medical College and Goa College of Pharmacy were established by the then Portuguese government in the year 1963. Followed by Goa Dental College in the year 1980, these three colleges were run by the Government of Goa. BhartiyaSanskritiPrabodhini'sGomantak Ayurveda Mahavidyalaya and Research Center and Institute of Nursing Education was established in the year 1993, Shivgram Education Society's Kamaxidevi Homeopathic Medical College was established in the year 1998, and Victor Medical and Research Foundation College of Nursing was established in the year 2005, PES College of Pharmacy Education and Research was established recently in the year 2007. 
Table 8.2

Library Staff Strength

\begin{tabular}{|c|c|c|}
\hline \multirow{2}{*}{ Name of the Institutions } & \multicolumn{2}{|c|}{ Total No. of Library Staff } \\
\hline & Less than 5 & 16 to 20 \\
\hline Goa Dental College & $1(12.5)$ & - \\
\hline Goa Medical College & - & $1(12.5)$ \\
\hline Goa College of Pharmacy & $1(12.5)$ & - \\
\hline B.S.P's GomantakAyurvedic College & $1(12.5)$ & - \\
\hline Kamaxi Homeopathic College & $1(12.5)$ & - \\
\hline PESCollege of Pharmacy & $1(12.5)$ & - \\
\hline Institute of Nursing Education & $1(12.5)$ & - \\
\hline VMRF College of Nursing & $1(12.5)$ & - \\
\hline Total & $7(87.5)$ & $1(12.5)$ \\
\hline
\end{tabular}

Table-10 demonstrates the library staff strength in the Medical and other college libraries under the study. It reveals that $87.5 \%$ college libraries under the study are having less than 5 library staff. $12.5 \%$ college library (i.e. GMC) is having 16 to 20 library staff respectively.

Table 8.3

Designation-wise Distribution of Library Staff

\begin{tabular}{|c|c|c|c|c|c|c|c|c|c|}
\hline \multirow[b]{2}{*}{ Designations } & \multicolumn{8}{|c|}{ Name of the Institutions } & \multirow[b]{2}{*}{ Total } \\
\hline & $\begin{array}{c}\text { Goa } \\
\text { Dental } \\
\text { College }\end{array}$ & $\begin{array}{c}\text { Goa } \\
\text { Medical } \\
\text { College }\end{array}$ & $\begin{array}{c}\text { Goa } \\
\text { College of } \\
\text { Pharmacy }\end{array}$ & $\begin{array}{c}\text { BSP G } \\
\text { Ayurvedic } \\
\text { College }\end{array}$ & $\begin{array}{c}\text { KamaxiHomeopathic } \\
\text { M. College }\end{array}$ & $\begin{array}{c}\text { PES } \\
\text { Pharmacy } \\
\text { College }\end{array}$ & $\begin{array}{c}\text { Institute } \\
\text { of } \\
\text { Nursing }\end{array}$ & $\begin{array}{l}\text { VMRF } \\
\text { Nursing } \\
\text { College }\end{array}$ & \\
\hline Librarian & - & $\begin{array}{c}1 \\
(12.5)\end{array}$ & 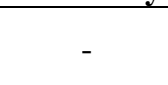 & $\begin{array}{c}1 \\
(12.5)\end{array}$ & $\begin{array}{c}1 \\
(12.5)\end{array}$ & $\begin{array}{c}1 \\
(12.5)\end{array}$ & $\begin{array}{c}1 \\
(12.5)\end{array}$ & (1) & $\begin{array}{c}5 \\
(62.5)\end{array}$ \\
\hline $\begin{array}{l}\text { Assistant } \\
\text { Librarian }\end{array}$ & - & $\begin{array}{c}1 \\
(12.5)\end{array}$ & - & - & - & - & - & $\begin{array}{c}1 \\
(12.5)\end{array}$ & $\begin{array}{c}2 \\
(25.0)\end{array}$ \\
\hline $\begin{array}{l}\text { Library } \\
\text { Assistants }\end{array}$ & $\begin{array}{c}1 \\
(12.5)\end{array}$ & $\begin{array}{c}1 \\
(12.5)\end{array}$ & $\begin{array}{c}1 \\
(12.5)\end{array}$ & $\begin{array}{c}1 \\
(12.5)\end{array}$ & $\begin{array}{c}1 \\
(12.5)\end{array}$ & - & - & - & $\begin{array}{c}5 \\
(62.5)\end{array}$ \\
\hline $\begin{array}{l}\text { System } \\
\text { Administrator }\end{array}$ & - & - & - & - & - & - & - & - & - \\
\hline $\begin{array}{l}\text { Computer } \\
\text { Programmer }\end{array}$ & - & - & - & - & - & - & - & - & - \\
\hline $\begin{array}{l}\text { Data Entry } \\
\text { Operator }\end{array}$ & - & - & - & - & - & - & - & - & - \\
\hline Clerks & - & $\begin{array}{c}1 \\
(12.5)\end{array}$ & $\begin{array}{c}1 \\
(12.5)\end{array}$ & - & - & - & - & - & $\begin{array}{c}2 \\
(25.0)\end{array}$ \\
\hline Peons & - & $\begin{array}{c}1 \\
(12.5)\end{array}$ & $\begin{array}{c}1 \\
(12.5)\end{array}$ & - & - & $\begin{array}{c}1 \\
(12.5)\end{array}$ & - & - & $\begin{array}{c}3 \\
(37.5)\end{array}$ \\
\hline Attendants & $\begin{array}{c}1 \\
(12.5)\end{array}$ & $\begin{array}{c}1 \\
(12.5)\end{array}$ & - & - & - & - & - & $\begin{array}{c}1 \\
(12.5)\end{array}$ & $\begin{array}{c}3 \\
(37.5)\end{array}$ \\
\hline
\end{tabular}

Table-8.3 illustrates the designation-wise distribution of the library staff. The study reveals that, five colleges out of eight colleges under the study are having full time librarians. Two college libraries are having one Asst. Librarian, whereas five colleges are having 1 to 4 
library assistants. Again two college libraries are having library clerks to look after the day to day administrative work in the library. And three colleges each are having peons and attenders respectively. None of the college libraries having data entry operators, system administrator and computer programmer to help librarian in providing uninterrupted computerized services effectively. It is interesting to note here that, Goa Dental College and Goa College of Pharmacy are managed by library assistants; VMRF Nursing College is managed by single assistant librarian.

Table 8.4

Age and Experience of the Librarian

\begin{tabular}{|c|c|c|c|c|c|c|c|c|c|}
\hline \multirow[b]{2}{*}{$\begin{array}{l}\text { Name of the } \\
\text { Institution }\end{array}$} & \multicolumn{4}{|c|}{ Age of the Librarian } & \multicolumn{5}{|c|}{ Experience of the Librarian } \\
\hline & $\begin{array}{c}\text { Less } \\
\text { than } \\
30\end{array}$ & $\begin{array}{l}31 \text { to } \\
35\end{array}$ & $\begin{array}{c}45 \text { to } \\
50\end{array}$ & $\begin{array}{c}\text { More } \\
\text { than } \\
\mathbf{5 0} \\
\end{array}$ & $\begin{array}{l}1 \text { to } 5 \\
\text { Years }\end{array}$ & $\begin{array}{l}6 \text { to } 10 \\
\text { Years }\end{array}$ & $\begin{array}{c}16 \text { to } \\
20 \\
\text { Years } \\
\end{array}$ & $\begin{array}{l}21 \text { to } \\
25 \\
\text { Years } \\
\end{array}$ & $\begin{array}{c}26 \text { to } \\
30 \\
\text { Years } \\
\end{array}$ \\
\hline $\begin{array}{l}\text { Goa Dental } \\
\text { College }\end{array}$ & - & - & - & $\begin{array}{c}1 \\
(12.5)\end{array}$ & - & - & - & - & $\begin{array}{c}1 \\
(12.5)\end{array}$ \\
\hline $\begin{array}{l}\text { Goa Medical } \\
\text { College }\end{array}$ & - & - & $\begin{array}{c}1 \\
(12.5) \\
\end{array}$ & - & - & - & $\begin{array}{c}1 \\
(12.5)\end{array}$ & - & - \\
\hline $\begin{array}{l}\text { Goa College of } \\
\text { Pharmacy }\end{array}$ & - & - & $\begin{array}{c}1 \\
(12.5)\end{array}$ & - & $\begin{array}{c}1 \\
(12.5)\end{array}$ & - & - & - & - \\
\hline $\begin{array}{l}\text { B.S.P's } \\
\text { GomantakAyurve } \\
\text { dic College }\end{array}$ & - & $\begin{array}{c}1 \\
(12.5)\end{array}$ & - & - & $\begin{array}{c}1 \\
(12.5)\end{array}$ & - & - & - & - \\
\hline $\begin{array}{l}\text { Kamaxi } \\
\text { Homeopathic } \\
\text { College }\end{array}$ & $\begin{array}{c}1 \\
(12 . \\
5)\end{array}$ & - & - & - & $\begin{array}{c}1 \\
(12.5)\end{array}$ & - & - & - & - \\
\hline $\begin{array}{l}\text { PESCollege of } \\
\text { Pharmacy }\end{array}$ & - & $\begin{array}{c}1 \\
(12.5)\end{array}$ & - & - & - & $\begin{array}{c}1 \\
(12.5)\end{array}$ & - & - & - \\
\hline $\begin{array}{l}\text { Institute of } \\
\text { Nursing } \\
\text { Education }\end{array}$ & - & - & - & $\begin{array}{c}1 \\
(12.5)\end{array}$ & - & - & - & $\begin{array}{c}1 \\
(12.5)\end{array}$ & \\
\hline $\begin{array}{l}\text { VMRF College } \\
\text { of Nursing }\end{array}$ & - & $\begin{array}{c}1 \\
(12.5)\end{array}$ & - & - & - & $\begin{array}{c}1 \\
(12.5)\end{array}$ & - & - & - \\
\hline Total & $\begin{array}{c}1 \\
(12 . \\
5)\end{array}$ & $\begin{array}{c}3 \\
(37.5)\end{array}$ & $\begin{array}{c}2 \\
(25.0)\end{array}$ & $\begin{array}{c}2 \\
(25.0)\end{array}$ & $\begin{array}{c}3 \\
(37.5)\end{array}$ & $\begin{array}{c}2 \\
(25.0)\end{array}$ & $\begin{array}{c}1 \\
(12.5)\end{array}$ & $\begin{array}{c}1 \\
(12.5)\end{array}$ & $\begin{array}{c}1 \\
(12.5)\end{array}$ \\
\hline
\end{tabular}

Table-8.4 clearly shows that the respondent's age and experience of the librarians working in Medical Colleges in Goa. 12.5\% librarians belonged to less than 30 years, 37.5\% librarians belonged to 31 to 35 years age group and $25 \%$ librarians each is aged between 45 to 50 and more than 50 years age group respectively. 
Further it is analyzed that $37.5 \%$ librarians are having less than 5 years of experience followed by $25 \%$ librarians are having 6 to 10 years of experience as a librarian $12.5 \%$ each librarians belonged to group of 16 to 20,21 to 25 and 26 to 30 years of experience. This table shows that, the majority of the librarians have experience between 16 to 30 years of experience.

Table 8.5

Collection of reading materials in the library

\begin{tabular}{|c|c|c|c|c|c|c|c|c|c|c|}
\hline \multirow[b]{2}{*}{$\begin{array}{l}\text { Reading } \\
\text { Materials }\end{array}$} & \multirow[b]{2}{*}{ Numbers } & \multicolumn{8}{|c|}{ Name of the Institutions } & \multirow[b]{2}{*}{ Total } \\
\hline & & GDC & GMC & $\mathrm{GCP}$ & $\begin{array}{l}\text { BSP } \\
\text { GAC }\end{array}$ & $\begin{array}{l}\mathrm{KH} \\
\mathrm{MC}\end{array}$ & $\begin{array}{l}\text { PES } \\
\text { PC }\end{array}$ & IN & $\begin{array}{l}\text { VMR } \\
\text { F NC }\end{array}$ & \\
\hline \multirow{3}{*}{ Books } & 1000 to 5000 & $\sqrt{ }$ & - & - & - & - & $\sqrt{ }$ & - & $\sqrt{ }$ & $3(37.5)$ \\
\hline & 5000 to 10000 & - & - & $\sqrt{ }$ & $\sqrt{ }$ & $\sqrt{ }$ & - & $\sqrt{ }$ & - & $4(50)$ \\
\hline & $\begin{array}{l}15001 \text { to } \\
20000\end{array}$ & - & $\sqrt{ }$ & - & - & - & - & - & - & $1(12.5)$ \\
\hline \multirow{6}{*}{ Journals } & Less than 10 & - & - & - & - & - & - & $\sqrt{ }$ & $\sqrt{ }$ & $2(25)$ \\
\hline & 10 to 20 & - & - & - & - & - & $\sqrt{ }$ & - & - & $1(12.5)$ \\
\hline & 21 to 30 & - & - & $\sqrt{ }$ & $\sqrt{ }$ & - & - & - & - & $2(25)$ \\
\hline & 31 to 40 & - & - & - & - & $\sqrt{ }$ & - & - & - & $1(12.5)$ \\
\hline & 41 to 50 & $\sqrt{ }$ & - & - & - & - & - & - & - & $1(12.5)$ \\
\hline & 100 to 200 & - & $\sqrt{ }$ & - & - & - & - & - & - & $1(12.5)$ \\
\hline \multirow{4}{*}{ Back Volumes } & No & - & - & - & $\sqrt{ }$ & $\sqrt{ }$ & - & $\sqrt{ }$ & $\sqrt{ }$ & $4(50)$ \\
\hline & $\begin{array}{l}\text { Less than } \\
1000\end{array}$ & - & - & $\sqrt{ }$ & - & - & $\sqrt{ }$ & - & - & $2(25)$ \\
\hline & 1000 to 5000 & $\sqrt{ }$ & - & - & - & - & - & - & - & $1(12.5)$ \\
\hline & $\begin{array}{l}10000 \text { to } \\
15000\end{array}$ & - & $\sqrt{ }$ & - & - & - & - & - & - & $1(12.5)$ \\
\hline \multirow{3}{*}{$\begin{array}{l}\text { Thesis/ } \\
\text { Dissertations }\end{array}$} & No & $\sqrt{ }$ & - & $\sqrt{ }$ & $\sqrt{ }$ & $\sqrt{ }$ & $\sqrt{ }$ & $\sqrt{ }$ & $\sqrt{ }$ & $7(87.5)$ \\
\hline & 20 to 30 & - & - & - & - & - & - & - & - & $1(12.5)$ \\
\hline & 500 to 1000 & - & $\sqrt{ }$ & - & - & - & - & - & - & $1(12.5)$ \\
\hline \multirow{2}{*}{$\begin{array}{l}\text { Gazette } \\
\text { Notifications }\end{array}$} & No & $\sqrt{ }$ & $\sqrt{ }$ & $\sqrt{ }$ & - & $\sqrt{ }$ & $\sqrt{ }$ & $\sqrt{ }$ & $\sqrt{ }$ & $7(87.5)$ \\
\hline & $\begin{array}{l}\text { Less than } \\
1000\end{array}$ & - & - & - & $\sqrt{ }$ & - & - & - & - & $1(12.5)$ \\
\hline \multirow{2}{*}{$\begin{array}{l}\text { Scientific/ } \\
\text { Technical } \\
\text { Reports }\end{array}$} & No & $\sqrt{ }$ & $\sqrt{ }$ & $\sqrt{ }$ & $\sqrt{ }$ & $\sqrt{ }$ & $\sqrt{ }$ & $\sqrt{ }$ & $\sqrt{ }$ & $8(100)$ \\
\hline & Less than 100 & - & - & - & - & - & - & - & - & - \\
\hline \multirow[b]{2}{*}{ Standards } & No & $\sqrt{ }$ & $\sqrt{ }$ & $\sqrt{ }$ & $\sqrt{ }$ & $\sqrt{ }$ & $\sqrt{ }$ & $\sqrt{ }$ & $\sqrt{ }$ & $8(100)$ \\
\hline & $\begin{array}{l}\text { Less than } \\
1000\end{array}$ & - & - & - & - & - & - & - & - & - \\
\hline \multirow[b]{2}{*}{ Patents } & No & $\sqrt{ }$ & $\sqrt{ }$ & $\sqrt{ }$ & $\sqrt{ }$ & $\sqrt{ }$ & $\sqrt{ }$ & $\sqrt{ }$ & $\sqrt{ }$ & $8(100)$ \\
\hline & $\begin{array}{l}\text { Less than } \\
1000\end{array}$ & - & - & - & - & - & - & - & - & - \\
\hline \multirow[b]{2}{*}{ e-databases } & No & $\sqrt{ }$ & $\sqrt{ }$ & - & $\sqrt{ }$ & $\sqrt{ }$ & $\sqrt{ }$ & $\sqrt{ }$ & $\sqrt{ }$ & $7(87.5)$ \\
\hline & $\begin{array}{l}\text { Less than } \\
1000\end{array}$ & - & - & $\sqrt{ }$ & - & - & - & - & - & $1(12.5)$ \\
\hline \multirow{2}{*}{ Floppies } & No & $\sqrt{ }$ & $\sqrt{ }$ & $\sqrt{ }$ & $\sqrt{ }$ & $\sqrt{ }$ & $\sqrt{ }$ & $\sqrt{ }$ & - & $7(87.5)$ \\
\hline & 21 to 30 & - & - & - & - & - & - & - & $\sqrt{ }$ & $1(12.5)$ \\
\hline \multirow{5}{*}{ CD-Roms } & No & - & $\sqrt{ }$ & - & - & $\sqrt{ }$ & $\sqrt{ }$ & - & - & $3(37.5)$ \\
\hline & Less than 10 & - & - & - & $\sqrt{ }$ & - & - & - & - & $1(12.5)$ \\
\hline & 10 to 20 & - & - & - & - & - & - & - & $\sqrt{ }$ & $1(12.5)$ \\
\hline & 21 to 30 & $\sqrt{ }$ & - & - & - & - & - & $\sqrt{ }$ & - & $2(25)$ \\
\hline & 40 to 50 & - & - & $\sqrt{ }$ & - & - & - & - & - & $1(12.5)$ \\
\hline \multirow{2}{*}{$\begin{array}{l}\text { Audio-Visual } \\
\text { Collections }\end{array}$} & No & $\sqrt{ }$ & $\sqrt{ }$ & $\sqrt{ }$ & $\sqrt{ }$ & $\sqrt{ }$ & $\sqrt{ }$ & $\sqrt{ }$ & $\sqrt{ }$ & $8(100)$ \\
\hline & Less than 100 & - & - & - & - & - & - & - & - & - \\
\hline
\end{tabular}


Table-8.5 analyzes the collection of reading materials in the medical college libraries under the study. One library namely Goa Dental College is having 1000 to 5000 books, and it subscribes 41-50 journals. The library is having 1000-5000 back volumes followed by the library is having 21-30 CD's. But it is surprising to record here that GDC is not having any thesis and dissertations, gazette notifications, scientific/technical reports, standards, patents, electronic databases, floppies and audio visual collection in their library.

On the other hand Goa Medical College library is having 15000 to 20000 books and it subscribes to 100-200 subject journals. The library is having 10000-15000 back volumes. The library is having 500-1000 thesis and dissertations. Again it is surprising to record here that Goa Medical College is not having any gazette notifications, scientific/technical reports, standards, patents, electronic databases, floppies, CD-ROMs and audio-visual collection in their library

Another college i.e. Goa College of Pharmacy is having a collection of 5000 to 10000 books and subscribes to 21-30 journals, having less than 1000 back volumes and 40-50 CDROMs. This college also does not have thesis/dissertations, gazette notifications, scientific and technical reports, standards, patents, electronic data bases, floppies, and Audio visual collection in their library.

Regarding BSP's GomantakAyurvedic College is concerned, it is having a collection of 5000 to 10000 books, and it subscribes to 21-30 journals followed by 1000 gazette notifications and less than 10 educational CD-ROMs are available. But it does not have any back volumes, thesis and dissertations, scientific/technical reports, standards, patents, electronic databases, floppies and audio visual collection in their library.

On the other hand Kamaxidevi Homeopathic Medical College is having 5000 to 10,000 books, and it subscribes 31-40 subject journals. But it does not have any back volumes, thesis and dissertations, scientific/technical reports, standards, patents, electronic databases, floppies, CD-ROMs and audio visual collection in their library. 
Another college under the study namely PES College of Pharmacy Education and Research is having 1000 to 5000 books, and it subscribes 10-20 journals. The library is having less than 1000 back volumes. But it is surprising to note that the pharmacy college is not having any thesis and dissertations, gazette notifications, scientific/technical reports, standards, patents, electronic databases, floppies, CD-ROMs and audio visual collection in their library.

Regarding Institute of Nursing is concerned, 5000 to 10000 books and subscribes to less than 10 subject journals, 21-30 CD-ROMs are available in this library. But it is surprising to record here that the Nursing College is not having any back volumes, thesis and dissertations, gazette notifications, scientific/technical reports, standards, patents, electronic databases, floppies and audio visual collection in their library.

Finally VMRF College of Nursing is having 1000 to 5000 books, and it subscribes to less than 10 current journals. The library is having 21-30 floppies and it is having 10-20 CD-ROMs. But it is interesting to note that VMRF College of Nursing is not having any back volumes, thesis and dissertations, gazette notifications, scientific and technical reports, standards, patents, electronic databases, and audio visual materials in their library.

It is observed from the study that, all the colleges under the study are not having scientific and technical reports, electronic databases, standards, patents and audio visual collection in their college libraries.

Table 8.6

Usage of the Library

\begin{tabular}{|c|c|c|c|c|c|c|c|c|c|c|}
\hline \multirow[b]{2}{*}{ Average No. of } & \multirow{2}{*}{$\begin{array}{l}\text { Number of } \\
\text { Users }\end{array}$} & \multicolumn{8}{|c|}{ Name of the Institutions } & \multirow[b]{2}{*}{ Total } \\
\hline & & GDC & GMC & GCP & $\begin{array}{l}\text { BSP } \\
\text { GAC }\end{array}$ & $\begin{array}{l}\mathrm{KH} \\
\mathrm{MC}\end{array}$ & $\begin{array}{c}\text { PES } \\
\text { PC }\end{array}$ & IN & $\begin{array}{c}\text { VMRF } \\
\text { NC }\end{array}$ & \\
\hline \multirow{3}{*}{$\begin{array}{l}\text { Visitors to the } \\
\text { Library }\end{array}$} & 21 to 30 & - & - & - & - & $\begin{array}{c}1 \\
(12.5)\end{array}$ & - & - & $\begin{array}{c}1 \\
(12.5)\end{array}$ & $\begin{array}{c}2 \\
(25)\end{array}$ \\
\hline & 50 to 100 & $\begin{array}{c}1 \\
(12.5)\end{array}$ & - & $\begin{array}{c}1 \\
(12.5)\end{array}$ & $\begin{array}{c}1 \\
(12.5)\end{array}$ & - & $\begin{array}{c}1 \\
(12.5)\end{array}$ & $\begin{array}{c}1 \\
(12.5)\end{array}$ & & $\begin{array}{c}5 \\
(62.5) \\
\end{array}$ \\
\hline & 101 to 200 & - & $\begin{array}{c}1 \\
(12.5)\end{array}$ & - & - & - & - & - & - & $\begin{array}{c}1 \\
(12.5)\end{array}$ \\
\hline \multirow{2}{*}{$\begin{array}{l}\text { Usage of } \\
\text { Reference Section }\end{array}$} & $\begin{array}{l}\text { Less than } \\
10\end{array}$ & - & - & - & $\begin{array}{c}1 \\
(12.5)\end{array}$ & - & - & $\begin{array}{c}1 \\
(12.5)\end{array}$ & $\begin{array}{c}1 \\
(12.5)\end{array}$ & $\begin{array}{c}3 \\
(37.5)\end{array}$ \\
\hline & 10 to 20 & - & - & - & - & $\begin{array}{c}1 \\
(12.5)\end{array}$ & - & - & - & $\begin{array}{c}1 \\
(12.5)\end{array}$ \\
\hline
\end{tabular}




\begin{tabular}{|c|c|c|c|c|c|c|c|c|c|c|}
\hline & 40 to 50 & $\begin{array}{c}1 \\
(12.5)\end{array}$ & - & $\begin{array}{c}1 \\
(12.5) \\
\end{array}$ & - & - & $\begin{array}{c}1 \\
(12.5)\end{array}$ & - & - & $\begin{array}{c}3 \\
(37.5)\end{array}$ \\
\hline & 50 to 100 & - & $\begin{array}{c}1 \\
(12.5)\end{array}$ & - & - & - & - & - & - & $\begin{array}{c}1 \\
(12.5)\end{array}$ \\
\hline \multirow{3}{*}{$\begin{array}{l}\text { Books Borrowed } \\
\text { in a Day }\end{array}$} & 10 to 20 & - & - & - & - & $\begin{array}{c}1 \\
(12.5)\end{array}$ & - & $\begin{array}{c}1 \\
(12.5)\end{array}$ & $\begin{array}{c}1 \\
(12.5)\end{array}$ & $\begin{array}{c}3 \\
(37.5)\end{array}$ \\
\hline & 40 to 50 & - & $\begin{array}{c}1 \\
(12.5) \\
\end{array}$ & - & $\begin{array}{c}1 \\
(12.5) \\
\end{array}$ & - & - & - & & $\begin{array}{c}2 \\
(25) \\
\end{array}$ \\
\hline & 50 to 100 & $\begin{array}{c}1 \\
(12.5) \\
\end{array}$ & - & $\begin{array}{c}1 \\
(12.5) \\
\end{array}$ & - & - & $\begin{array}{c}1 \\
(12.5) \\
\end{array}$ & - & - & $\begin{array}{c}3 \\
(37.5) \\
\end{array}$ \\
\hline \multirow{3}{*}{ Bound Volumes } & No & - & - & - & $\begin{array}{c}1 \\
(12.5)\end{array}$ & $\begin{array}{c}1 \\
(12.5)\end{array}$ & - & $\begin{array}{c}1 \\
(12.5)\end{array}$ & $\begin{array}{c}1 \\
(12.5)\end{array}$ & $\begin{array}{c}4 \\
(50) \\
\end{array}$ \\
\hline & 10 to 20 & - & - & - & - & - & $\begin{array}{c}1 \\
(12.5)\end{array}$ & - & & $\begin{array}{c}1 \\
(12.5) \\
\end{array}$ \\
\hline & 21 to 30 & $\begin{array}{c}1 \\
(12.5) \\
\end{array}$ & $\begin{array}{c}1 \\
(12.5) \\
\end{array}$ & $\begin{array}{c}1 \\
(12.5) \\
\end{array}$ & - & - & - & - & - & $\begin{array}{c}3 \\
(37.5) \\
\end{array}$ \\
\hline \multirow{5}{*}{$\begin{array}{l}\text { Current Issues } \\
\text { Consulted in a } \\
\text { Day }\end{array}$} & No & - & - & - & $\begin{array}{c}1 \\
(12.5) \\
\end{array}$ & $\begin{array}{c}1 \\
(12.5)\end{array}$ & - & - & - & $\begin{array}{c}2 \\
(25) \\
\end{array}$ \\
\hline & $\begin{array}{l}\text { Less than } \\
10\end{array}$ & - & - & - & - & - & $\begin{array}{c}1 \\
(12.5)\end{array}$ & $\begin{array}{c}1 \\
(12.5)\end{array}$ & $\begin{array}{c}1 \\
(12.5)\end{array}$ & $\begin{array}{c}3 \\
(37.5)\end{array}$ \\
\hline & 10 to 20 & $\begin{array}{c}1 \\
(12.5)\end{array}$ & - & - & - & - & - & - & - & $\begin{array}{c}1 \\
(12.5)\end{array}$ \\
\hline & 21 to 30 & - & - & $\begin{array}{c}1 \\
(12.5)\end{array}$ & - & - & - & - & - & $\begin{array}{c}1 \\
(12.5) \\
\end{array}$ \\
\hline & 30 to 40 & - & $\begin{array}{c}1 \\
(12.5) \\
\end{array}$ & - & - & - & - & - & - & $\begin{array}{c}1 \\
(12.5) \\
\end{array}$ \\
\hline \multirow{3}{*}{$\begin{array}{l}\text { Usage of e- } \\
\text { resources in a day }\end{array}$} & No & $\begin{array}{c}1 \\
(12.5) \\
\end{array}$ & - & $\begin{array}{c}1 \\
(12.5) \\
\end{array}$ & $\begin{array}{c}1 \\
(12.5) \\
\end{array}$ & $\begin{array}{c}1 \\
(12.5) \\
\end{array}$ & $\begin{array}{c}1 \\
(12.5) \\
\end{array}$ & $\begin{array}{c}1 \\
(12.5) \\
\end{array}$ & $\begin{array}{c}1 \\
(12.5) \\
\end{array}$ & $\begin{array}{c}7 \\
(87.5) \\
\end{array}$ \\
\hline & $\begin{array}{l}\text { Less than } \\
10\end{array}$ & - & - & - & - & - & - & - & - & - \\
\hline & 51 to 75 & - & $\begin{array}{c}1 \\
(12.5)\end{array}$ & - & - & - & - & - & - & $\begin{array}{c}1 \\
(12.5)\end{array}$ \\
\hline
\end{tabular}

An attempt is made to identify the daily usage of the library under the study, and the same is reported in table-8.6. It is observed from the study that 101 to 200 users are visiting to GMC College libraries under the study. Followed by 50 to 100 users are visiting in five college libraries namely GDC, GCP, BSPGAC, PESPC, and IN and only 21 to 30 users are visiting in KHMC and VMRFCN college libraries daily.

As for as reference services are concerned less than 10 users are using references services in BSPAC, IN and VMRFCN followed by 10 to 20 users are using reference services in KHMC library, 40 to 50 users in GDC, GCP and PESPC, and in GMC 50 to 100 users are making use of reference services daily. As for as circulation service is concern 10 to 20 books are circulated in a day in KHMC, IN and VMRFNC college libraries, followed by 40 to 50 books in GMC and BSPGAC college libraries and 50 to 100 books are circulated daily in GDC, GCP and PESPC college libraries. 
Four colleges namely BSPGAC, KHMC, IN and VMRFNC users are not at all consulted the bound volumes of journals in their respective libraries, whereas, only one college i.e. PESPC users are consulted the 10 to 20 bound volumes. GDC, GMC and GCP College library users are consulted 21 to 30 bound volumes in a day.

Again two colleges under the study namely BSPGAC and KHMC college users are not consulting the current issues of the journals, but very less number of users i.e. less than 10 users are consulting the current issues of the journals in PESPC, IN and VMRFCN colleges. 10 to 20, 21 to 30 and 30 to 40 users are referring current issues of journals daily in GDC, GCP and GMC college libraries respectively. As for as using of e-resources are concern GDC, GCP, BSPGAC, KHMC, PESPC, IN and VMRFCN college users are not using this service, only in GMC college library 51 to 75 users are using electronic resources.

Table 8.7

Courses offered by the Institutions

\begin{tabular}{|l|c|c|}
\hline \multicolumn{1}{|c|}{ Name of the Institution } & Under Graduate & Post Graduate \\
\hline Goa Dental College & $1(12.5)$ & $1(12.5)$ \\
\hline Goa Medical College & $1(12.5)$ & $1(12.5)$ \\
\hline Goa College of Pharmacy & $1(12.5)$ & $1(12.5)$ \\
\hline B.S.P's G Ayurvedic College & $1(12.5)$ & - \\
\hline K Homeopathic College & $1(12.5)$ & - \\
\hline PESC Pharmacy & $1(12.5)$ & - \\
\hline Institute Nursing Education & $1(12.5)$ & - \\
\hline VMRF College of Nursing & $1(12.5)$ & $3(37.5)$ \\
\hline \multicolumn{1}{|c|}{ Total } & $8(100)$ & . \\
\hline
\end{tabular}

Table-8.7 clearly depicts that, three out of eight colleges under the study are offering both undergraduate and post-graduate courses in Medical, Dental and Pharmacy, whereas remaining colleges are offering only undergraduate courses. 
Table 8.8

Built up and stack area in the library

\begin{tabular}{|c|c|c|c|c|c|c|c|}
\hline \multirow[b]{2}{*}{ Name of the Institutions } & \multicolumn{4}{|c|}{ Built up Area } & \multicolumn{3}{|c|}{ Stack Area } \\
\hline & $\begin{array}{c}\text { Less } \\
\text { than 500 } \\
\text { Sq .mt. }\end{array}$ & $\begin{array}{c}1001 \text { to } \\
1500 \text { Sq. } \\
\text { mt }\end{array}$ & $\begin{array}{l}1501 \text { to } \\
2000 \\
\text { Sq. } \mathrm{mt}\end{array}$ & $\begin{array}{l}4001 \text { to } \\
5000 \\
\text { Sq.mt }\end{array}$ & $\begin{array}{c}\text { Less } \\
\text { than 500 } \\
\text { Sq .mt. }\end{array}$ & $\begin{array}{l}501 \text { to } \\
1000 \\
\text { Sq.mt }\end{array}$ & $\begin{array}{c}1001 \text { to } \\
1500 \mathrm{Sq} \text {. } \\
\mathrm{mt}\end{array}$ \\
\hline Goa Dental College & $1(12.5)$ & - & - & - & $1(12.5)$ & - & - \\
\hline Goa Medical College & - & - & - & $1(12.5)$ & - & - & $1(12.5)$ \\
\hline Goa College of Pharmacy & $1(12.5)$ & - & - & - & $1(12.5)$ & - & - \\
\hline $\begin{array}{l}\text { B.S.P's Gomantak Ayurvedic } \\
\text { College }\end{array}$ & - & - & $1(12.5)$ & - & - & $1(12.5)$ & - \\
\hline Kamaxi Homeopathic College & $1(12.5)$ & - & - & - & $1(12.5)$ & - & - \\
\hline PES College of Pharmacy & $1(12.5)$ & - & - & - & $1(12.5)$ & - & - \\
\hline Institute of Nursing Education & - & $1(12.5)$ & - & - & $1(12.5)$ & - & - \\
\hline VMRF College of Nursing & $1(12.5)$ & - & - & - & $1(12.5)$ & - & - \\
\hline Total & $5(62.5)$ & $1(12.5)$ & $1(12.5)$ & $1(12.5)$ & $6(75.0)$ & $1(12.5)$ & $1(12.5)$ \\
\hline
\end{tabular}

Built up area and stack area of the libraries under the study is depicted in table-8.8. Five college libraries under the study are having less than 500 Square Meter built up area, one each college libraries are having 1001 to 1500 Square Meter and 1501 to 2000 and 4001 to 5000 Square meters built up area respectively. Further it is analysed that $75 \%$ of the libraries under the study are having less than 500 Square Meter of stack area, followed by one library is having 501 to 1000 Square Meters and another one library is having 1001 to 1500 Sq.mt. stack area in the library.

Table 8.9

Availability of different sections in the library

\begin{tabular}{|l|c|c|}
\hline \multicolumn{1}{|c|}{ Name of the Institutions } & No & 2 to 4 sections \\
\hline Goa Dental College & $1(12.5)$ & - \\
\hline Goa Medical College & - & $1(12.5)$ \\
\hline Goa College of Pharmacy & - & $1(12.5)$ \\
\hline B.S.P's GomantakAyurvedic Medical College & - & $1(12.5)$ \\
\hline Kamaxi Homeopathic Medical College & - & $1(12.5)$ \\
\hline PES College of Pharmacy & - & $1(12.5)$ \\
\hline Institute of Nursing Education & $1(12.5)$ & - \\
\hline VMRF College of Nursing & $1(12.5)$ & - \\
\hline \multicolumn{1}{|c|}{ Total } & $3(37.5)$ & $5(62.5)$ \\
\hline
\end{tabular}


Investigator made an attempt to know the availability of different sections (i.e.:Reference Section, Circulation Section, Technical Section, Internet Section etc) in the library. The collected data is tabulated and presented in table-8.9. The table clearly shows that five libraries under the study are having 2 to 4 sections and remaining college libraries do not have any separate sections in the library.

Table 8.10

Availability of separate section for E-resources

\begin{tabular}{|l|c|c|}
\hline \multicolumn{1}{|c|}{ Name of the Institutions } & Yes & No \\
\hline Goa Dental College & - & $1(12.5)$ \\
\hline Goa Medical College & $1(12.5)$ & - \\
\hline Goa College of Pharmacy & - & $1(12.5)$ \\
\hline B.S.P's GomantakAyurvedic College & - & $1(12.5)$ \\
\hline Kamaxi Homeopathic Medical College & - & $1(12.5)$ \\
\hline PESCollege of Pharmacy & - & $1(12.5)$ \\
\hline Institute of Nursing Education & - & $1(12.5)$ \\
\hline VMRF College of Nursing Total & - & $1(12.5)$ \\
\hline \multicolumn{1}{|c|}{ Ty is } & $1(12.5)$ & $7(87.5)$ \\
\hline
\end{tabular}

It is observed from the above table- 8.10 that, only one college library (i.e. GMC) under the study is having a separate section for the electronic resources and remaining seven college libraries do not have a separate section for the electronic resources in their libraries.

Table 8.11

Seating capacity in the Reading Hall

\begin{tabular}{|c|c|c|c|}
\hline \multirow{2}{*}{ Name of the Institutions } & \multicolumn{3}{|c|}{ Seating Capacity } \\
\hline & 30 to 40 & 40 to 50 & 51 to 100 \\
\hline Goa Dental College & - & - & $1(12.5)$ \\
\hline Goa Medical College & - & - & $1(12.5)$ \\
\hline Goa College of Pharmacy & - & - & $1(12.5)$ \\
\hline B.S.P's GomantakAyurvedic College & - & $1(12.5)$ & - \\
\hline Kamaxi Homeopathic Medical College & $1(12.5)$ & - & - \\
\hline PES College of Pharmacy & $1(12.5)$ & - & - \\
\hline Institute of Nursing Education & - & - & $1(12.5)$ \\
\hline VMRF College of Nursing & - & $1(12.5)$ & - \\
\hline Total & $2(25.0)$ & $2(25.0)$ & $4(50.0)$ \\
\hline
\end{tabular}


Table-8.11 clearly demonstrates the seating capacity of the reading hall; each two libraries under the study are having 30 to 40 and 40 to 50 seating capacity and four libraries are having 51 to 100 seating capacity in their libraries.

\section{Findings:}

8.1 In the earlier days, Goa government established the medical, dental, pharmacy and nursing colleges, recently private homeopathic, ayurveda, nursing and pharmacy colleges.

8.2 It reveals that $87.5 \%$ college libraries under the study are having less than 5 library staff. $12.5 \%$ college library (i.e. GMC) is having 16 to 20 library staff respectively.

8.3 The study reveals that, five colleges out of eight colleges under the study are having full time librarians.

$8.412 .5 \%$ librarians belonged to less than 30 years, $37.5 \%$ librarians belonged to 31 to 35 years age group and $25 \%$ librarians each is aged between 45 to 50 and more than 50 years age group respectively. The majority of the librarians have experience between 16 to 30 years of experience.

8.5 All the colleges under the study are not having scientific and technical reports, electronic databases, standards, patents and audio visual collection in their college libraries.

8.6 As for as reference services are concerned less than 10 users are using references services in BSPAC, IN and VMRFCN followed by 10 to 20 users are using reference services in KHMC library, 40 to 50 users in GDC, GCP and PESPC, and in GMC 50 to 100 users are making use of reference services daily.

8.7 As for as using of e-resources are concern GDC, GCP, BSPGAC, KHMC, PESPC, IN and VMRFCN college users are not using this service, only in GMC college library 51 to 75 users are using electronic resources. 
$8.875 \%$ of the libraries under the study are having less than 500 Square Meter of stack area.

8.9 Only one college library (i.e. GMC) under the study is having a separate section for the electronic resources and remaining seven college libraries do not have a separate section for the electronic resources in their libraries.

8.10 Each two libraries under the study are having 30 to 40 and 40 to 50 seating capacity and four libraries are having 51 to 100 seating capacity in their libraries.

\section{Recommendations}

9.1 Library staff strength should be increased as there is a acute shortage of library staff compared to their users strength, resources, services available in the respective college libraries.

9.2 To make more use of journals / magazines librarian should bring international/national level subject related journals in both print and electronic format. At the same time librarian has to make awareness about the journals by taking photography of contents pages and sending it to the all the related faculties for circulation through WhatsApp and one hard copy has to be put on the library notice board so, students will also aware of these journal contents.

9.3 Provide separate reading room facility for the teachers and make a digital library section separately and provide more number of e-resources.

9.4 To increase the users in day, library should have more number of anti-virus installed computers connected with high speed internet connectivity, and skilled staff (computer technician/operator) to solve the problems and to guide the users in using the e-resources in the library.

9.5 Librarian has to take initiation in computerization of all the library housekeeping operations for the easy of library administration.

9.6 The most important function of a library staff is to give prime importance to accessibility of library resources and provide comfortable environment for the study. 


\section{Conclusions}

The management of information from a wide range of sources is a basic ingredient in the success of any library. The information explosion around the world is increasing enormously and the libraries simply cannot manage the huge amount of information manually without the use of modern IT tools and techniques. Libraries should acquire modern tools and techniques time to time for providing effective information to their user community in a shortest possible time.

\section{References}

11.1 Biradar, B. S., Anita, S., \& Ushalatha, D. K. (2001). Periodicals Use Pattern by Medical Practitioners of Shimoga City. Annals of Library and Information Studies, 48(2), 65-71.

11.2 Directorate of Technical Education. (2011, May 26). About Us: Directorate of Technical Education, . Retrieved from Government of Goa: www.dtegoa.gov.in

11.3 Institute of Nursing Education. (2010 - 2011). Annual Report. Panaji: Directorate of Medical Education, Government of Goa.

11.4 Pandya, S. K. (1982). Medicine in Goa - A Former Portuguese Territory. Journal of Post-Graduate Medicine, 28(3), 123-148.

11.5 Ranasinghe, P., Wickramasinghe, S. A., Pieris, W. R., Karunthilake, I., \& Godwin, R. C. (2012). Computer Literacy among First Year Medical Students in a Developing Country. BMC Research Notes, 5(504), 500-504.

11.6 Reddy , H. K., \& Karisiddappa, C. (1997). Information Seeking Behaviour of the Professionals in the field of disabilities with special reference to mental handicap in India. Annals of Library Science and Documentation, 44(2), 54-64. 
11.7 Singh, K. P., \& Satija, M. P. (2007, December). Information seeking behaviour of agricultural scientists with particular reference to their information seeking strategies. Annals of Library and Information Studies, 54(12), 213 - 220.

11.8 Varadan, S. K. (1954-1955). Pharmacy Education in the State of Madras. Indian Pharmacists, 10, 309-311. 